\title{
Lexis
}

Journal in English Lexicology

Book reviews | 2009

\section{Howard JACKSON, Key Terms in Linguistics}

Continuum, 2007, 192 pages

\section{Deny A. Kwary}

\section{(2) OpenEdition}

Journals

\section{Electronic version}

URL: http://journals.openedition.org/lexis/1937

DOI: $10.4000 /$ lexis. 1937

ISSN: 1951-6215

\section{Publisher}

Université Jean Moulin - Lyon 3

\section{Electronic reference}

Deny A. Kwary, "Howard JACKson, Key Terms in Linguistics », Lexis [Online], Book reviews, Online since 25 March 2009, connection on 23 September 2020. URL : http://journals.openedition.org/lexis/1937 ; DOI : https://doi.org/10.4000/lexis.1937

This text was automatically generated on 23 September 2020.

\section{(c) (i) (9)}

Lexis is licensed under a Creative Commons Attribution-NonCommercial-NoDerivatives 4.0 International License. 


\title{
Howard JACKSON, Key Terms in Linguistics
}

Continuum, 2007, 192 pages

\author{
Deny A. Kwary
}

\section{REFERENCES}

Howard Jackson

Key Terms in Linguistics. Continuum, London, 2007. ISBN: 97880826487421, Prix : £14.99,

192 pages

1 Professor Howard Jackson has written eight textbooks and numerous articles on grammar, vocabulary and lexicography. As with his other books (e.g. Words, Meaning and Vocabulary, Good Grammar for Students, and Lexicography: an Introduction), Key Terms in Linguistics (KTiL) is also aimed at undergraduate students. According to the preface of KTiL, the target user is a beginning student of language or linguistics who is undertaking one of the British GCE A-level courses in English Language, or is in the first year or so of a degree course in linguistics, English language, or a modern language.

2 KTiL is quite small for a dictionary of linguistics, though there are both advantages and disadvantages in this. In terms of physical size, it is $21.4 \times 13.8 \times 1.6 \mathrm{~cm}$ and it contains fewer than 200 pages. With 654 entries only, it is quite possible that a student might encounter in his/her study a term which is not included in KTiL. However, Jackson states in the Preface that if a student cannot find a term that he/she is looking for, Jackson asks to be informed, via the publishers, so that the term can be included in any subsequent edition: a rare offer and one that should be welcomed.

3 The terms included in KTiL are grouped into eleven thematic headings, covering a total of 153 pages. The eleven headings, as well as the number of pages and number of entries for each heading are as follows: 


\begin{tabular}{|l|l|l|l|}
\hline 1 & Phonetics and Phonology & 18 pages & 87 entries \\
\hline 2 & Grammar: Morphology and Syntax & $\mathbf{4 0}$ pages & 170 entries \\
\hline 3 & Semantics and Pragmatics & $\mathbf{9}$ pages & 41 entries \\
\hline $\mathbf{4}$ & Discourse and Text Analysis & $\mathbf{1 2}$ pages & $\mathbf{4 9}$ entries \\
\hline 5 & Sociolinguistics & $\mathbf{1 1}$ pages & 54 entries \\
\hline 6 & Psycholinguistics & $\mathbf{1 1}$ pages & $\mathbf{4 4}$ entries \\
\hline 7 & Historical Linguistics & $\mathbf{8}$ pages & $\mathbf{3 5}$ entries \\
\hline $\mathbf{8}$ & Applied Linguistics & $\mathbf{7}$ pages & $\mathbf{2 8}$ entries \\
\hline $\mathbf{9}$ & Stylistics & $\mathbf{8}$ pages & $\mathbf{3 4}$ entries \\
\hline $\mathbf{1 0}$ & Corpus Linguistics & $\mathbf{9}$ pages & $\mathbf{3 8}$ entries \\
\hline $\mathbf{1 1}$ & Schools of Linguistics & $\mathbf{1 5}$ pages & $\mathbf{7 4}$ entries \\
\hline
\end{tabular}

4 As mentioned, the total number of entries is 654 . This is a lot smaller than some other dictionaries of linguistics. Matthews's The Concise Oxford Dictionary of Linguistics contains over 3,150 entries, while Trask's Language and Linguistics: The Key Concepts also contains more than 3,000 entries. The smaller scope of KTiL is however justified by the fact that it is aimed at beginning students of language or linguistics.

5 There are at least three aspects of KTiL which I feel make it especially useful for its target readership, and where lecturers teaching introductory courses on Linguistics, especially in EFL environments, may find it useful for student reading lists, as a reference book. These are its layout, the introductory explanations of key areas, and its accessibility.

6 The layout of the articles is very attractive in terms of legibility because the font is at the right size and the line spacing is quite wide. The font size of KTiL is $10 \mathrm{pt}$, which has been suggested as ideal for printed texts of this kind. Paterson and Tinker (1929) who studied a number of typographical issues found that for paper, $10 \mathrm{pt}$ text was read faster than $6,8,12$, or $14 \mathrm{pt}$. The readability of the texts in KTiL is enhanced by the wide spacing, and the fact that headword and its definition are placed in separate paragraphs. All of these make the reading process more relaxing and therefore the text easier to follow than is, for example, with some other dictionaries where the font size is very small and the lines are put very close to one another.

7 Another merit of KTiL are the introductory explanations that open every thematic grouping. Jackson starts each with a brief description of what the theme is about. Jackson also includes website addresses and textbooks related to the headings. The following is an example of an article found on the first page of the Corpus Linguistics section (p. 129): 


\section{Corpus Linguistics}

8 An empirical method of linguistic analysis and description that uses a corpus as its primary data and starting point. This method is in contrast to introspective linguistics (sometimes called 'armchair' linguistics), where the linguist describes a language on the basis of their own knowledge and speculate about the nature of language on this basis. See the website 'Text Corpora and Corpus Linguistics': www.athel.com/ corpus.html devoted to corpora. An introductory textbook is McEnery \& Wilson (2001).

In some articles, Jackson does not only provide the definitions of the terms, but also related websites to the headwords. The following is an example of an article found within the Corpus Linguistics section (p. 131):

\section{Concordance}

10 A list of all the occurrences of a (key) word in a corpus, together with a specified amount of co-text on either side of the keyword, i.e. in KWICformat. A concordance is produced by a piece of concordancing software, e.g. MonoConc (www.monoconc.com), WordSmith Tools (www.lexically.net/wordsmith/index.html). Concordancing software is the basic tool of corpus linguists.

11 In addition to the website addresses and textbooks mentioned in the articles, Jackson also provides a list of key readings (pp. 155-162). For Corpus Linguistics, Jackson lists the following books as its Key Readings:

MCENERY, T. \& WILSON, A. (2001) Corpus Linguistics, Second Edition, Edinburgh

University Press.

TEUBERT, W. \& CERMÁKOVÁ, A. (2007) Corpus Linguistics: A Short Introduction,

Continuum.

SAMPSON, G. \& MCCARTHY, D. (2005) (eds) Corpus Linguistics: Readings in a Widening

Discipline, Continuum.

12 The key readings section is divided into twelve sections, eleven of them corresponding to the thematic headings while the remainder is labelled 'General'. Under this General heading, Jackson listed two encyclopaedias (Crystal 1997 and Malmkjaer 2004) and two introductory textbooks on linguistics (Hall 2005 and Yule 2006).

13 The third strong feature of KTiL is the convenient system of access routes shown in the pairing of terms under the same entry and also in the index. An example of the pairing of terms is bound and free (morphemes) which are put under one entry, i.e. bound/free. This arrangement is helpful for comprehension, because a student who wants to know the definition of a bound morpheme will also be likely to look for the definition of a free morpheme, in order to confirm and contextualize the difference. In the KTiL, both are put in one entry on page 25. In, for example the Concise Oxford Dictionary of Linguistics (Matthews, 1997), the entry bound is on page 41 , while the entry free is on page 135, without any cross reference to the page number of the other. Other examples of pairing in KTiL are Active/Passive, Competence/Performance, Flap/Tap, Syntacmatic/ Paradigmatic, Langue/Parole, etc.

14 In addition to access routes via the thematic headings, Jackson also provides alphabetical access to the terms via the index. This lists all terms in the main text, along with page numbers for each. It would therefore be easy for all students, whether 
native speakers or not, to locate the terms which they were looking for. Other dictionaries such as Trask's Language and Linguistics: The Key Concepts, list key terms alphabetically but without page numbers. In this case, the access route given by Jackson is better than that of Trask.

One of the shortcomings of KTiL is the selection of terms. In the Preface, Jackson mentions that his choice of terms for KTiL is based on his experience of teaching language and linguistics for over thirty-five years and on his examination of other works of a similar nature. The problem with this approach is that there is a high probability of missing some entries which are actually related to other entries. For example, there are entries for future perfect (p. 36) and past perfect (p. 46), but there is no entry for present perfect. Another example is in the section on Phonetics and Phonology, where Jackson mentions Acoustic Phonetics, but omits the other two branches, i.e. Articulatory Phonetics and Auditory Phonetics. These three terms are closely related and important for the students to know, and they are mentioned in Matthews's dictionary (pp. 5, 26, and 29) and Trask's dictionary (p. 215). They are also mentioned in introductory linguistic textbooks, such as Introduction to Language (Fromkin, Rodman \& Hyams 2007: 223) and The Study of Language (Yule 2006: 30).

The same problem can be found in the section on Grammar: Morphology and Syntax. Although overall this section has the highest number of entries, some related terms are still missing. In this section, there are entries for prefix, suffix, and suprafix (or superfix), but there is no entry for infix. Matthews (1997) mentions five types of affixes: prefix, suffix, infix, circumfix, and superfix; Trask (2007) mentions four types: prefix, suffix, infix, and superfix; Fromkin, Rodman, and Hyams (2007) mentions four types prefix, suffix, infix, and circumfix: whereas Yule (2006) mentions three types: prefix, suffix, and infix. Considering those lists, Jackson should either mention these three types: prefix, suffix, and infix or all five, i.e. including superfix and circumfix or accommodate the students who use Yule's textbook and Fromkin, Rodman, and Hyams's textbook.

Since Jackson is a British based linguist, it is common to find more British references than the American ones. Take an example from the Corpus linguistics section again. Corpora created in the U.K.-Bank of English, British National Corpus, International Corpus of English, and Oxford English Corpus-are put as entries, while the corpora created in the U.S. is barely mentioned. It is true that the best-known English language corpora are created in the U.K. and Europe, but there are also corpora from the U.S. which should be included in the entries, particularly the Brown Corpus of Standard American English (the first significant corpus of English) and the ongoing Corpus of Contemporary American English (www.americancorpus.org).

Despite these shortcomings, this reviewer finds KTiL an excellent addition to the field, especially if it is to be used as a reference book for an undergraduate student in EFL environments who needs brief and simple descriptions of Linguistics. 


\section{BIBLIOGRAPHY}

CRYSTAL David, The Cambridge Encyclopedia of Language, Cambridge, Cambridge University Press, 1997.

FROMKIN V, RODMAN R. \& HYAMS N., Introduction to Language, Boston, Thomson Wadsworth, 2007.

HALL C. J., An Introduction to Language and Linguistics, London: Continuum, 2005.

MALMKJAER K. (ed.), The Linguistics Encyclopedia, London, Routledge, 2004.

MATTHEWs P., The Concise Oxford Dictionary of Linguistics, Oxford, Oxford University Press, 1997.

PATERSON D.G., TINKER M.A., "Studies of Typographical Factors Influencing Speed of Reading: II. Size of Type", Journal of Applied Psychology, 13:2, 1929: 120-130.

TRASK R. L., Language and Linguistics: The Key Concepts, Oxon, Routledge, 2007.

YULE G., The Study of Language, Cambridge, Cambridge University Press, 2006.

\section{AUTHORS}

\section{DENY A. KWARY}

Deny A. Kwary, Centre for Lexicography, Aarhus School of Business, University of Aarhus, Denmark.

Deny A. Kwary has been a lecturer of English Language and Linguistics at Airlangga University, Indonesia, since 1996. He has a personal website www.kwary.net which has provided free learning materials since 2004 and has been widely used by students and lecturers from many countries. Currently he is taking a PhD in Lexicography at the Centre for Lexicography, Aarhus School of Business, University of Aarhus, Denmark. His current research is on Metalexicographic and Computational Features of LSP Dictionaries. 